\title{
Professor Maliyasena Dhammadasa Dassanayake: A Felicitation to an Illustrious Teacher and Botanist of Our Time
}

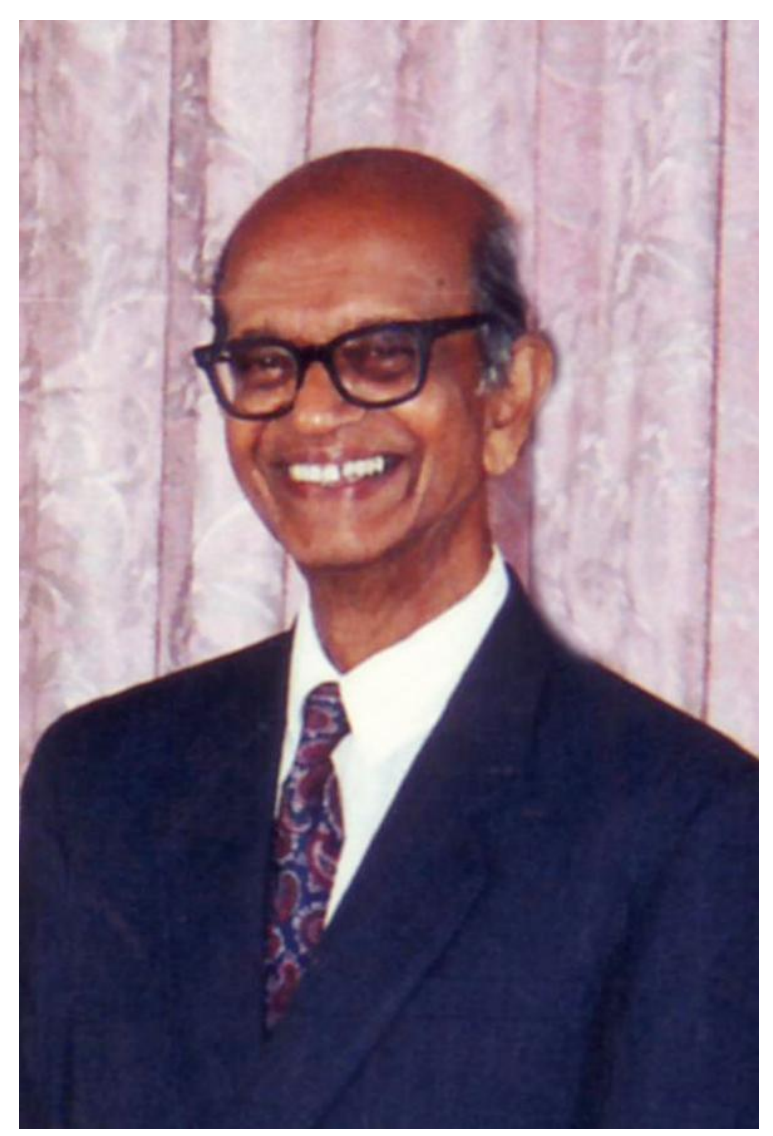

Prof. Maliyasena Dhammadasa Dassanayake, a colossus in Sri Lanka's botanical landscape and General Editor of the Ceylon Journal of Science in the 1980 's, is an erudite scholar and an academic par excellence. Now, at the age of 94 , he spends a quiet and contented life with his wife Ms. Chitra Ratwatte in their home in a tranquil environment in Dangolla, a 'stone's throw' from the Peradeniya University where he spent much of his illustrious academic life. At present he devotes some of his time to reading and enriching his spiritual life. Also, he and his wife very much enjoy meeting friends, past students and colleagues who visit them. Through this article we write to document the exemplary life and works of this unpretentious scholar, a role model to emulate, based mostly on our personal experiences and engagement with him over the past several decades.

Early Life: On 17th September 1921, Mr. D.M.W. Dassanayake, a Registrar of Marriages and Births and his spouse Ms. R.M. Madawala were the proud parents of Maliyasena Dhammadasa Dassanayake, their youngest child, born in Kurunegala. His siblings were Pemananda then 10 years old and his 8 year old sister Kamala. The young Dassanayake received his primary education at the Government Boys' School, Kuliyapitiya. His secondary education was at Dharmaraja College Kandy, from where he successfully completed his London Matriculation Examination in 1938, qualifying to pursue a medical degree; only 17 years then, he was underage to enter Ceylon University College. Therefore, he stayed on at school in the Post-Matriculation class waiting till he was 18 years, the eligible age when one could go on for higher studies. During his last year at Dharmaraja College, he was also invited by the Principal to teach at Maliyadeva College, Kurunegala. It was a time when there was no free education in the country. Parents had to meet the cost of tertiary education as Ceylon, like most other countries, was grappling to absorb the after-shocks of the devastating effects of the 1930s Great Depression. Under these circumstances young Dassanayake had to forego the opportunity to enter Medical School and instead read for a science degree at the Ceylon University College and later University of Ceylon located in the metropolis of Colombo (1939-1943). He was in the first batch of three students reading for the Botany special degree. His colleagues were Messers. Bala Tampo and E.E. Jeyaraj; among his contemporaries was the Late Prof. Senaka Bibile (1920-1977) in the Premedical Class in the Ceylon University College. He completed the first degree, qualifying with Second Class Honours. This was the gateway to his post-graduate studies in England, funded by the University of Ceylon. Young Dassanayake read for his M.A. Degree (1948-1950) at the University of Cambridge, qualifying with Natural Tripos Part II Botany. His Ph. D. (1955-1957) was from the University of Manchester, where he researched on "Aspects of Morphogenesis in Dorsiventral Ferns", under the tutelage of Late Prof. C.W. Wardlaw (1901-1985), who was then the Professor of Cryptogamic Botany at the University.

Carrier Record: Dr. Dassanayake's professional carrier record in his specialized field of Botany began way back in 1945. His first appointment was to the Botany Department of the University of Ceylon in Colombo, founded in 1942 (when the island had only one university). He served there for 17 years, first as an assistant lecturer (1945-1950) and then as a lecturer (1950-1967). Thereafter, he joined the Peradeniya Campus of the University of Ceylon, a residential campus, described by Sir Ivor Jennings as 'one of the finest small universities in the world', where he served till his retirement in 1988, inspiring the youth of the country and enjoying its salubrious climate amidst lush vegetation and misty mountains. Dr. Dassanayake's career at the Peradeniya campus 
started as a Senior Lecturer (1967-1968), then as a Reader (1968-1973) and finally he went on to be the Professor and Head of the Department of Botany (1973-1988). It was during his headship that the Peradeniya Campus became independent of the University of Ceylon and a fully-fledged University of its own. It is noteworthy that Professor Dassanayake has the honour of being the first Head of the Botany Department in the University of Peradeniya and held this post till his retirement in 1988.

The Teacher: Prof. Dassanayake was a teacher to be emulated and admired. Striking features about him were his simplicity in dress and life style and his modest and unassuming nature that has never changed. His manner of teaching was admirable. He had that special gift of imparting hard to understand material in a very simple way. So much so that students were not only very attentive at his lectures, but felt that the subject was easy. He had a very kind and friendly disposition. Anyone could approach him easily without apprehensions. Yet, he was strict about maintaining academic standards that he expected from his students, and did not hesitate to correct them when they did something wrong or failed to perform up to his expectations. His knowledge on Botany was exhaustive. Yet, he would be a passive listener when junior staff expressed their botanical/ecological field experiences that excited them. Subsequently, he would often draw their attention to published material on the subject, guiding them and stimulating their interest even further. Prof. Dassanayake never grudged sharing his time generously with his students and junior staff, who often requested him to edit their project proposals, manuscripts or even applications to higher institutes for their post- graduate degrees. Another endearing quality of Prof. Dassanayake was his extraordinary level of humility. When academics, past students and colleagues visited him at the university, he would most often than not accompany them down to the lobby of the Botany Department to see them off, making them feel much appreciated.

As the Patron of the Botanical Society of the University of Peradeniya, Prof. Dassanayake always encouraged and supported the activities the society carried out. He enjoyed participating in the events of the society enthusiastically: the annual 'shramadana' in the Botany Department and its environs was one of them; students, academic and non-academic staff would join as one group to clean up the department garden, weeding flower beds, cutting the grass, pruning overgrown branches, and most importantly it was an opportunity for everyone in the department (whether academic staff member, non-academic staff member or student) to interact freely and get to know each other better in an informal surrounding. Most importantly, it was also an occasion to pay back in a small way the enormous benefits both students and staff received from the university and to instill a sense of belonging to the department one studied in.

Outside Prof. Dassanayake's university duties, his other contributions to further education and science were many. As a young academic staff member at the University of Ceylon Colombo Campus, guided by his peers, he was an examiner in Botany for the Ceylon University Entrance and Advanced Level Examinations (1954-1967). The Faculty of Science of the Batticaloa University College, during its formative years was affiliated to the University of Peradeniya. Then, Prof. Dassanayake's experience and expertise was much sought after and he was appointed a member of the Advisory Committee (1981-1986) for formulating lecture programs and moderating examination papers in Botany. He was also a member of the Coconut Research Board, Lunuwila, Sri Lanka from 1976-1978. The University of Zambia too, benefitted from Prof. Dassanayake's expertise and knowledge when he was selected as a visiting Professor in Botany (19781980), during his sabbatical leave. Prof. Dassanayake is a life member of the Ceylon/Sri Lanka Association for the Advancement of Science, and was the Sectional President of the Natural Sciences Section in 1962, and its General Secretary from 1958-1961. In the Natural History Society of Ceylon, he was President in 1968. He was an Associate Editor (1970 -1986) and Chief Editor (1982-1986) of the Ceylon Journal of Science (Biological Sciences). In all these societies he has always been an active participant, contributing selflessly to the progress of each one of them.

Contributions to Sri Lanka's flora and plant genetic resources: Prof. Dassanayake's major research contribution to furthering the knowledge on Sri Lanka's plant sciences is through two projects, viz., (i) through his indispensable role in the Flora of Ceylon Project and (ii) to the Plant Genetic Resources Centre of the Department of Agriculture. The Flora of Ceylon Project was the brainchild of Late Prof. B.A. Abeywickrama (1920-2011), yet another colossus of Sri Lankan Botany. The project mooted by him was brought to fruition in 1967 at a meeting with the Late Dr. F.R. Fosberg (1908-1993), Special Advisor for Tropical Biology at the Smithsonian Institution, Washington, D.C., USA. Its aim was to revise the existing 'Handbook to the Flora of Ceylon' (18931900) by Dr. Henry Trimen, which at its time, was one of the most comprehensive and outstanding floras available for any comparable tropical area of the world.

Contribution to The Flora of Ceylon Project: This project was co-sponsored by the Smithsonian Institution, USA, Department of Agriculture, Peradeniya and University of Peradeniya. It was financially supported by the United States of America 
through the United States excess foreign currency under the provision of Public Law 480. At its inception, Dr. Fosberg from Washington D.C., served as the project's Principal Investigator and Prof. Abeywickrama was the Co-principal Investigator. Soon afterwards Prof. M.D. Dassanayake, the Late Dr. J.W.L. Peiris (Deputy Director-Research, Department of Agriculture), Late Mr. D.M.A. Jayaweera (Superintendent, Royal Botanical Gardens) and Late Mr. K.L.D. Amaratunga (Systematic Botanist, Department of Agriculture) were appointed as Co-principal Investigators.

The main outcome of this monumental project was a complete taxonomic revision of the angiosperm and fern flora of Ceylon, culminating in the publication of the 'Revised Handbook to the Flora of Ceylon' in 15 volumes, collectively spanning 7,062 pages and published over a period of 26 years (1980-2006). At its initiation, Prof. Dassanayake and Dr. Fosberg, until the latter's demise in 1993, and then with Dr. W.D. Clayton of the Royal Botanic Gardens, Kew, U.K., were the co-editors. The first 14 volumes documented the taxonomy of Sri Lanka's 220 families of flowering plants, followed by an Index Volume. The $15^{\text {th }}$ and final volume of the present series published the taxonomy of the island's Ferns and Fern-allies, representing 60 families. Prof. Dassanayake was its General Editor and Dr. Monika Shaffer-Fehre, Royal Botanic Gardens, Kew, U.K. its Editor.

From inception to completion, a period of nearly four decades of the Revised Flora of Ceylon Project, Prof. Dassanayake had the herculean task of meticulously editing and proof-reading its drafts and manuscripts, revealing his academic competence and utmost dedication to the field of plant taxonomy. During this period, he also needed to communicate with about 75 authors the world over, each a specialist in his or her own field of plant taxonomy, and the publishers. This was a time that modern technology, such as computers, email, internet, Skype etc., were unknown. Prof. Dassanayake accomplished this monumental undertaking with a typewriter and used the normal postal facilities. In the early years of the Flora of Ceylon Project, even photocopying facilities were not easily available, and documents had to be sent to the Smithsonian Institution for duplication. Innumerable hours of literature checking were done by him in libraries at the University of Peradeniya, The National Herbarium in the Royal Botanical Garden Peradeniya and Central Agricultural Research Institute (now Horticultural Research and Development Institute) at Gannoruwa etc. Without using any official vehicles of the Flora Project or of the University, he was frequently seen driving his family vehicle (the maroon Renault-1 Sri 8109, by then decades old), to commute to these places. His academic environment certainly was not limited to the precincts of the University of Peradeniya, but to its outskirts, and through exchange of drafts and manuscripts between the respective specialists of each taxonomic family to the world at large. In editing manuscripts on the revised plant families submitted by various authors, Prof. Dassanayake often used only a pencil and an eraser; he assured that these manuscripts were carefully scrutinized, the grammar perfected and taxonomically accurate before they were sent to the publisher. To the best of our knowledge much of this massive and timeconsuming task was delivered on an honorary capacity, a rare feat nowadays.

During the career of one of the authors of this article (MJ) in the Flora of Ceylon Project as a graduate research assistant and subsequently a collaborator, he had a rare opportunity to assist many foreign botanists of international repute. Then it had become MJ's regular habit to meet Prof. Dassanayake at the Botany Department and brief him about the project's progress, especially about exciting botanical findings in the field in different parts of the island which the Professor loved to know about. Frequently specimens of rare plants that were difficult to identify were brought and shown to him and he demonstrated the process of identification which enriched MJ's skills to a great deal. Sometimes the Professor joined MJ on these field visits. During one of them a plant new to science, Brachystelma lankana Dassanayake \& Jayasuriya (published in Ceylon Journal of Science, Vol. 11:1. 1974) was discovered. It belonged to the milk weed family (Asclepiadaceae). Till then the genus Brachystelma was only known in India and Africa. Writing MJ's first ever research paper jointly with Professor Dassanayake was an opportunity for this young graduate assistant to develop his writing skills in taxonomy, and a great honour to his personal research career.

Contribution to the Plant Genetic Resources Centre (PGRC): On retirement from the University of Peradeniya in 1988, Prof. Dassanayake was honoured with an appointment as a Consultant at the Plant Genetic Resources Centre, a new institute of the Department of Agriculture, Sri Lanka, established in 1988 with the financial and technical assistance from the Government of Japan. His Japanese counterpart was Dr. Shinji Watanabe, an expert in the conservation and utilization of plant genetic resources (PGRs). Prof. Dassanayake's main roles were to ensure a standard taxonomic basis for the PGR collection and its database and to provide guidance to the officers in its Plant Exploration and Evaluation Divisions. Dr. Watanabe, an equally senior, gentle and knowledgeable scientist, provided great friendship and cooperation to Prof. Dassanayake and together they produced some excellent publications on the PGRC activities in Sri Lanka. These provided 
the teaching material for subsequent PGR training programs at the PGRC.

As fate would have it, it was during this time that MJ was appointed the Director of the PGRC, giving him the opportunity to benefit again from Prof. Dassanayake's long experience and intellectual prowess. At the PGRC, Prof. Dassanayake helped to initiate and conduct training and development programs by inculcating a team spirit and responsibility among all grades of the staff. Among its activities was a series of five annual international training programs (2000-2004), supported by The Japan International Corporation Agency (JICA), to train selected PGR scientists in South and South East Asia, and later extended it even to African countries. Each of the one month-long courses included lectures, laboratory work, field sessions in demonstration plots and excursions, and helped to elevate the PGRC to a recognized PGR Training Centre in Asia. Prof. Dassanayake played a pivotal role in this endeavor, by formulating its course structure, selection of resource persons including foreign scientists, delivering lectures, conducting examinations and preparation of certificates that were awarded to trainees on completion of the course.

Awards and accolades: In appreciation of the long years of distinguished and dedicated service rendered to the University System in Sri Lanka, scientific institutions, scientific community and country at large, Prof. Dassanayake was awarded the status of Professor Emeritus by the University of Peradeniya in 1989. Other accolades and awards to honour him are: his appointment as a Fellow of the National Academy of Sciences in 1985; two university prizes established in 1991 that are awarded each year; they are (i) The Prof. M.D. Dassanayake Cash Prize presented to the best student at the Special Part I Examination in Botany and (ii) The Prof. M.D. Dassanayake Gold Medal awarded to the best student at the Special Degree Examination in Botany. In 1996, a plant species in the tea family, endemic to Sri Lanka and restricted to lower montane forests of Badulla and Nuwara Eliya districts in Sri Lanka was discovered by the plant taxonomists B.M. Wadhwa (Royal Botanic Gardens, Kew, U.K.) and A. Weerasooriya (Sri Lanka). This species new to science was named as Gordonia dassanayakei, to honor Prof. M.D. Dassanayake for his contributions to the Botany of Sri Lanka. In 2004, the Institute of Biology in Sri Lanka felicitated him for his outstanding and dedicated Service for the Advancement of Biology in the island. In 2011, in honour of Prof. Dassanayake's outstanding scientific achievements and contributions to the country, he was inducted to the Hall of Fame of the Sri Lanka Association for the Advancement of Science-Section D.

At four score and 14 years, Prof. Dassanayake still has a very vivid memory and continues to inspire the young and not so young academics and others who visit him. Coming from a Buddhist background, he meditates and contemplates on life, a practice going far back to the 1980's or even earlier. Meditation was introduced to him by his late father at a tender age of 10 years during their frequent visits to the Aswedduma Temple in Kuliyapitiya. His move to Peradeniya, rekindled his childhood interest in meditation, and led him to actively participate regularly in group dialogues and discussions on the Dhamma at Gatembe Rajopawanaramaya. These meetings were led by the Late Mr. Godwin Samararatne (1932-2000), a celebrated Buddhist scholar along with the leading priests of the temple. Even to date, he reads scholarly Buddhist texts and engages in Dhamma discussions with like-minded people who visit him at home. This undoubtedly may be the secret of his excellent memory and calm and composed demeanor that enables him to respond positively to adversities in life. Prof. Dassanayake epitomizes how to age gracefully and we still have a lot more to learn from him. For those of us who have had the privilege of being his students, his colleagues and later his friends, life is indeed much richer by associating him. Together with the many generations of students he has nurtured, we collectively extend our heartfelt and sincere thanks to this illustrious teacher, mentor and friend. We wish Prof. Dassanayake and Mrs. Dassanayake the blessings of the Noble Triple Gem for good health and many more happy years with their immediate and extended family, his family friends and well-wishers.

\section{Savitri Gunatilleke ${ }^{1 *}$, Magdon Jayasuriya ${ }^{2}$ and Nimal Gunatilleke ${ }^{1}$}

1 Professor Emeritus, University of Peradeniya, Peradeniya, Sri Lanka.

2 Senior Consultant, EML Consultants Pvt. Ltd., Kotte, Sri Lanka.

*Corresponding author: savnim@gmail.com 